\title{
Neural differentiation of the human neuroblastoma cell line IMR32 induces production of a thyrotropin-releasing hormone-like peptide
}

\author{
Jan M.M. Rondeel ${ }^{\mathrm{a}, *}$, Willem Klootwijk ${ }^{\mathrm{b}}$, Esther Linkels ${ }^{\mathrm{a}}$, Wim J. de Greef ${ }^{\mathrm{a}}$, \\ Theo J. Visser ${ }^{b}$ \\ ${ }^{a}$ Department of Endocrinology and Reproduction, Erasmus University Medical School, PO Box 1738, 3000 DR Rotterdam, Rotterdam, \\ The Netherlands \\ ${ }^{\mathrm{b}}$ Department of Internal Medicine III, Erasmus University Medical School, Rotterdam, The Netherlands
}

Accepted 6 September 1994

\begin{abstract}
The human neuroblastoma cell line IMR32 produces and secretes substantial amounts of TRH-immunoreactivity (TRH-IR) as measured with radioimmunoassay (RIA) using the nonspecific antiserum 4319. It was found that synthesis of TRH-IR is dependent on neural differentiation: under serum-free conditions these cells exhibit neural characteristics as defined by morphological and biochemical standards. After culture for 2-5 days in serum-free medium cells grew large neural processes and expressed neuron-specific markers whereas glial-specific markers were absent. TRH-IR became detectable after 4-8 days serum-free conditions. Northern blot and chromatographic analysis, however, failed to detect proTRH mRNA and authentic TRH in these cells. Moreover, TRH-IR was undetectable in the RIA using TRH-specific antiserum 8880. TRH-IR produced by differentiated cells was retained on a QAE Sephadex A-25 anion-exchange column and thus negatively charged. HPLC analysis showed coelution with the synthetic peptide pGlu-Glu-ProNH ${ }_{2}$. Study of the mechanisms regulating production of this novel peptide in these cells should further elucidate the role differentiation plays in the synthesis of neuropeptides.
\end{abstract}

Keywords: TRH; Cell line; Neuroblastoma; IMR32 pyroglutamyl-glutamyl-prolineamide; Neuron; differentiation

\section{Introduction}

Elucidation of the mechanisms by which the hypothalamus regulates hormone synthesis through gene transcription, processing and intracellular sorting of its prohormones necessitates a cell culture system of neural, preferably hypothalamic origin. As yet there are no naturally occurring neural cell lines that produce one of the major hypothalamic hormones [32]. For example, the rat CA77 cell-line produces TRH [33] but is derived from a medullary thyroid carcinoma, and regulation of proTRH gene expression in these cells differs from in vivo hypothalamic regulation $[16,39]$. Since only part of the neurons producing the releasing hormones within the hypothalamus are hypophysiotropic (i.e. se-

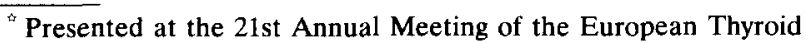
Association, Cardiff, Wales, 1993.

* Corresponding author. Fax: (31) (10) 4366832.
}

crete their hormones in portal blood) and some of them are very sparse, such as LHRH producing neurons, the use of primary cultures of hypothalamic neurons necessitates large numbers of cells [32]. One way to overcome this is to transfect cells, known to contain a prohormone-processing machinery with the genomic DNA of the prohormone. Another approach is the use of targeted tumorigenesis: only in the case of LHRH [21] and, recently, CRH [23] did this result in immortalized hypothalamic cell lines expressing the respective hormones.

Neuroblastoma cells are undifferentiated cells derived from the neural crest and have extensively been studied as a model of neural differentiation in view of the association between maturation of human neuroblastoma cells and regression of this highly malignant childhood tumour in vivo $[1,41]$. These cells have been reported to produce different neuropeptides $[5,26,27$, $36,37]$ and neurotransmitters $[12,13,34]$ and thus constitute an alternative model for neural peptide synthesis. 
The present study shows that these cells produce TRH-like immunoreactivity dependent on neural differentiation.

\section{Materials and methods}

\subsection{Cell cultures}

The human neuroblastoma cell line IMR32 [42] was provided by Dr. Versteeg (Academic Hospital Leiden, The Netherlands). Cells were cultured in $75 \mathrm{~cm}^{2}$ flasks containing $25 \mathrm{ml}$ Dulbecco's Modified Eagle's medium (DMEM) with $10 \%$ fetal calf serum, $500 \mathrm{U}$ penicillin, $500 \mu \mathrm{g}$ streptomycin and $2 \mathrm{mM} \mathrm{L-glutamine.} \mathrm{At} 80 \%$ confluency (approximately $30 \times 10^{6}$ cells) the medium was changed and cells were grown under serum free conditions in DMEM and Ham's F-12 nutrient mixture ( $1: 1)$ to induce neural differentiation. Medium was changed every $2-3$ days.

\subsection{Radioimmunoassays and DNA fluorimetry}

Cells were extracted in $5 \mathrm{ml}$ methanol, the extract was sonicated and centrifuged at $2,000 \times g$, and the supernatant was air-dried. The samples were reconstituted in $0.5 \mathrm{ml}$ RIA buffer and assayed for TRH immunoreactivity (TRH-IR) as previously described [43]. This assay was usually performed with antiserum 4319 (final dilution $1: 10,000)$ which has a low specificity for the His residue in TRH ( $<$ EHP- $\mathrm{NH}_{2}$ ). Antiserum 8880 (final dilution 1:40,000), which was raised in our laboratory by similar methods as used for antiserum 4319 , shows much less crossreactivity with analogs that have His replaced by other amino acids. Whereas the cross-reactivity of $<$ EFP-NH ${ }_{2}$ and <EEP-NH ${ }_{2}$ in the RIA with antiserum 4319 amounts to $100 \%$ or more, the activity is $5 \%$ and $<0.1 \%$, respectively, in the RIA with antiserum 8880 . The detection limit (defined as the amount of hormone that reduces binding to $90 \%$ of that occurring in the absence of unlabeled hormone) of the TRH assay is 2-3 pg, and the intra- and interassay variations are between 4 and $10 \%$. All samples from one experiment were run in one assay. Medium was directly assayed without extraction. Preliminary studies showed that the medium did not affect antibody binding parameters in our RIA and that TRH and the TRH-like peptide < EEP- $\mathrm{NH}_{2}$ were not degraded after a $48 \mathrm{~h}$ incubation period in the aforementioned media.

The DNA content of part of the cell lysates in $0.1 \mathrm{~N} \mathrm{NaOH}$ was determined by a fluorimetric assay using 3,5-diaminobenzoic acid dihydrochloride (DABA) as a fluorescent dye (Aldrich-Chemie, Steinheim, Germany). Samples were neutralized with $1 \mathrm{~N} \mathrm{HCl}$. A 50 $\mu l$ portion of the neutralized sample was mixed with $50 \mu l 1.5 \mathrm{M}$ DABA and incubated for $45 \mathrm{~min}$ at $60^{\circ} \mathrm{C}$. Subsequently, $2 \mathrm{ml} 1 \mathrm{~N}$
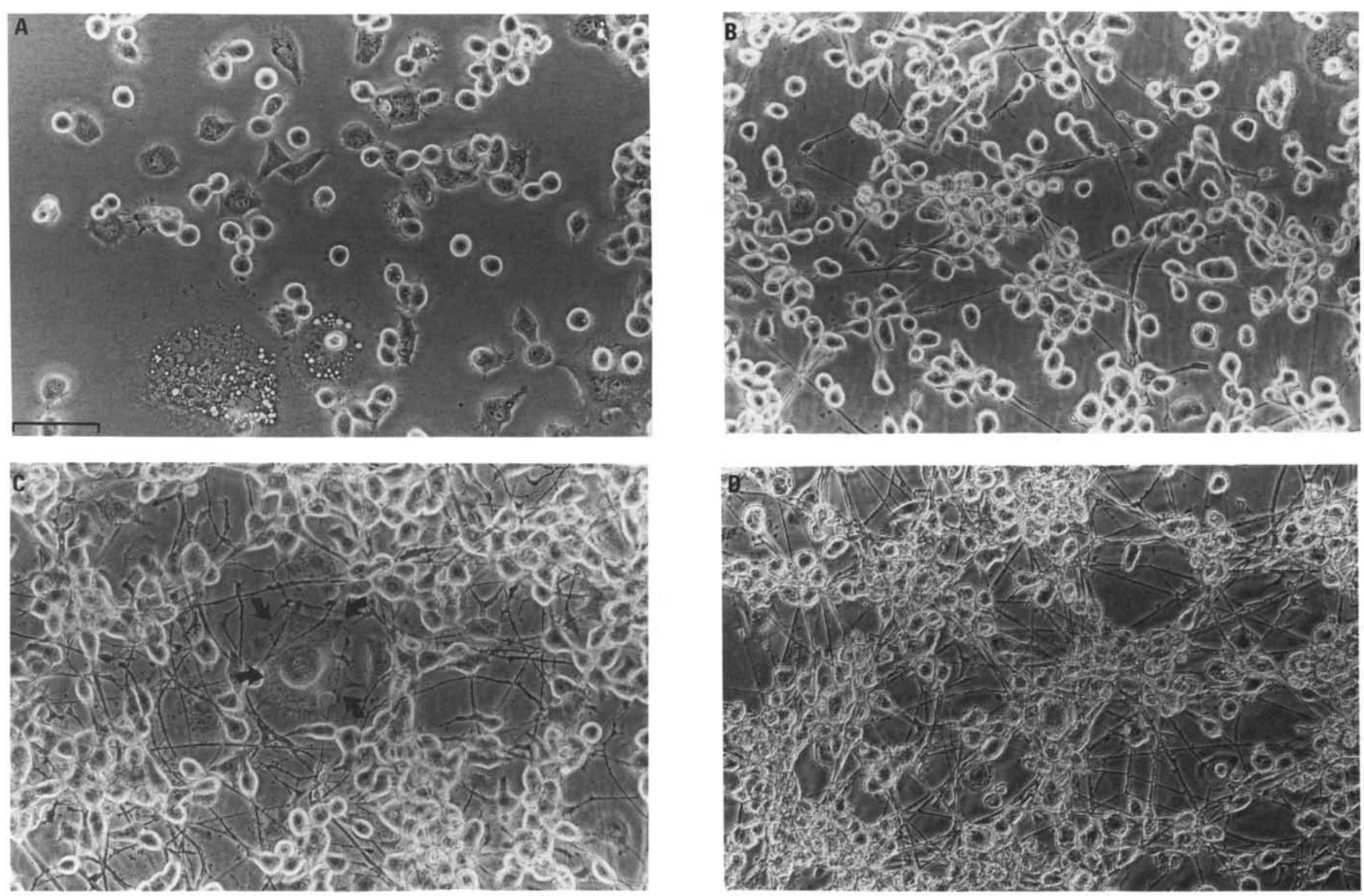

Fig. 1. Morphologic characteristics of IMR32 cells during serum-free culturing. Cells were grown in serum-containing medium (A) and, subsequently, in serum-free medium for 5 (B), 7 (C) and 10 (D) days. Undifferentiated cells (A) consist of highly light-refractile round neuroblast-like cells and larger spindle-shaped fibroblast-like cells. An occasional very large vacuole-containing macrophage-like cell can be seen. After 5 days of culture in serum-free medium the predominant round cells grow in tight clusters and extend thin and long processes (B). These processes get more numerous, thicker and longer during prolonged serum-free culture (C and $D$ ). Note the mature neuron-like cell in $C$ (within arrows). $\operatorname{Bar}(\mathrm{A})=100 \mu \mathrm{m}$. 
$\mathrm{HCl}$ was added and the fluorescence of the samples was measured using a Perkin Elmer fluorimeter at wavelengths of $415 \mathrm{~nm}$ (excitation) and $500 \mathrm{~nm}$ (emission). Calf thymus DNA was used as a standard.

\subsection{Chromatography}

For chromatography, pooled medium was acidified to $\mathrm{pH} 1.8-2.0$ with trifluoracetic acid (TFA) and purified over a Sep-Pak C18 cartridge (Waters). Care was taken to minimize contamination by using disposable materials whenever possible. Methanol-eluted TRH-IR fractions were pooled, air-dried and reconstituted in 2-4 ml $0.05 \mathrm{M}$ Tris $/ \mathrm{HCl} \mathrm{pH} 7.6$, containing $0.02 \mathrm{M}$ sodium azide $\left(\mathrm{NaN}_{3}\right)$. Subsequently, samples were applied to an anion-exchange column (QAE Sephadex A-25; $1.5 \times 10 \mathrm{~cm}$ ) and TRH-IR was eluted in $2 \mathrm{ml}$ fractions with a linear gradient of $50 \mathrm{ml} 0.05 \mathrm{M}$ Tris $/ \mathrm{HCl}\left(+\mathrm{NaN}_{3}\right)$ and $50 \mathrm{ml} 0.5 \mathrm{M} \mathrm{NaCl}$ in $0.05 \mathrm{M}$ Tris $/ \mathrm{HCl}$ with $\left(+\mathrm{NaN}_{3}\right)$. $\left[{ }^{125} \mathrm{I}\right]<$ EHPG ([ $\left.{ }^{125} \mathrm{I}\right] \mathrm{TRH}$-Gly) was used as a marker. Fractions were directly assayed in RIA and those containing TRH-IR were pooled, acidified with TFA and desalted over Sep-Pak C18 cartridges as described above. Again, the methanol fractions were pooled, air-dried and applied to a Vydac 218TP C18 reverse phase HPLC column $(25 \times 0.46 \mathrm{~cm}, 5 \mu \mathrm{m}$ particles, $300 \AA$ A pore size $)$. Isocratic elution was performed with $1.75 \%$ acetonitrile in $0.1 \%$ TFA at a flow rate of 1.0 $\mathrm{ml} / \mathrm{min}$. Fractions were directly analyzed by RIA. Standards were added to cell culture medium and treated in the same way as samples obtained from the IMR32 cells. Recovery of TRH and/or $<$ EEP-NH $\mathrm{NH}_{2}$ over Sep-Pak, anion-exchange and HPLC columns amounted to $85-90 \%$.

\subsection{Northern blot analysis}

Total RNA was extracted using the acid guanidinium phenolchloroform method described by Chomczynski [7]. RNA samples were electrophoresed and transferred to a nylon membrane (Hybond-N +, Amersham) using routine procedures [18]. The membrane was hybridized with ${ }^{32} \mathrm{P}$-labelled cRNA (for proTRH) or cDNA probes as described previously [18]. cDNA probes were generated with random primer labelling. The generation of a proTRH cRNA probe is described elsewhere [18]. A pCD169 vector containing the $2.5 \mathrm{~kb}$ rat neuron-specific enolase (NSE) cDNA [9] and the rat chromogranin $\mathrm{B}$ cDNA cloned in $\mathrm{pHG} 327$ [10] were kindly provided by Dr. S. Forss-Petter (Research Institute of Scripps Clinic, La Jolla, CA). The full length mouse glial fibrillary acidic protein (GFAP) cDNA clone G1 in pUC [19] and the mouse $68 \mathrm{kDa}$ neurofilament polypeptide cDNA, NF68, in pUC [20] were provided by Dr. N.J. Cowan (New York University, New York, NY). The pGEM-3Z vector containing a full length human proTRH cDNA [44] was provided by Dr. J.F. Wilber (University of Maryland, Baltimore, $\mathrm{MD})$. The rat cDNA clone $\mathrm{p} 27$ of brain myelin proteolipid protein (PLP) cloned in pUC 18 [22] was provided by Drs. R.J. Milner and J.G. Sutcliffe (Research Institute of Scripps Clinic, La Jolla, CA). A plasmid containing a $1.1 \mathrm{~kb}$ fragment of rat atrial peptidylglycine $\alpha$-amidating monooxygenase (PAM-1) cDNA cloned in Bluescript SK [35] was provided by Dr. B.A. Eipper (Johns Hopkins University, Baltimore, MD). A hamster actin cDNA probe was used to correct for minor differences in recovery.

\section{Results}

Fig. 1 shows morphologic characteristics of cells grown in serum-containing medium (undifferentiated cells) and cells grown in serum-free medium (differen-

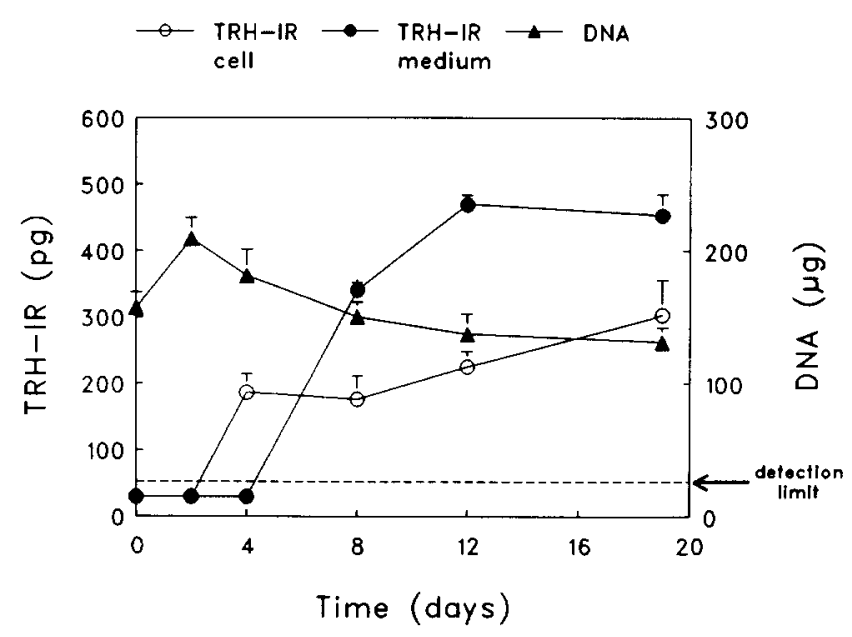

Fig. 2. Time course of cellular DNA content $(\mu \mathrm{g})$ and TRH-IR in medium ( $\mathrm{pg} /$ day) and extracts of IMR32 neuroblastoma cells (pg) as determined by RIA using the nonspecific antiserum 4319 . Cells were grown in serum-containing medium until near confluency (d0) and subsequently in serum-free medium for 19 days. Data represent means \pm S.E.M. of $4-5$ flasks per time point. The detection limit of the RIA is depicted. The TRH-specific antiserum 8880 could not detect TRH-IR in medium or cells irrespective of differentiation.

tiated cells). Undifferentiated cells consisted of two morphologically distinct cell types: the predominant cell type was a small round highly light refractile neuroblast-like cell, growing densely with focal accumulations as described previously [42]. A second cell type was a somewhat larger fibroblast-like and spindleshaped cell growing diffusely and wide spread (Fig. 1A). Cells grown under serum-free conditions showed drastic changes in morphology after 3-5 days (Fig. 1B). Differentiated cells stemmed from the predominant cell type and formed tight clusters extending long processes radially from the periphery and that connected cells together. These cells contained numerous growth cones. The thickness and length of the neurites was variable and increased during differentiation (Fig. 1BD). Morphologic differentiation - defined as increase in amount, length and thickness of neurites - was maximal after 10-12 days (Fig. 1D).

The time-dependent change of medium TRH-IR as determined by RIA using the nonspecific antiserum 4319 in medium and expressed as pg release/day, and cellular content of TRH-IR and DNA are depicted in Fig. 2. During serum-free conditions there was a gradual decline of DNA in these cells, while cellular content and release of TRH-IR in the medium steadily increased. TRH-IR was first detectable after 3-5 days serum free culturing and showed a plateau after 12 days. The medium contained more TRH-IR than the cells. TRH-IR was not detected with antiserum 8880 in medium or cells (not shown) irrespective of differentiation. 
C
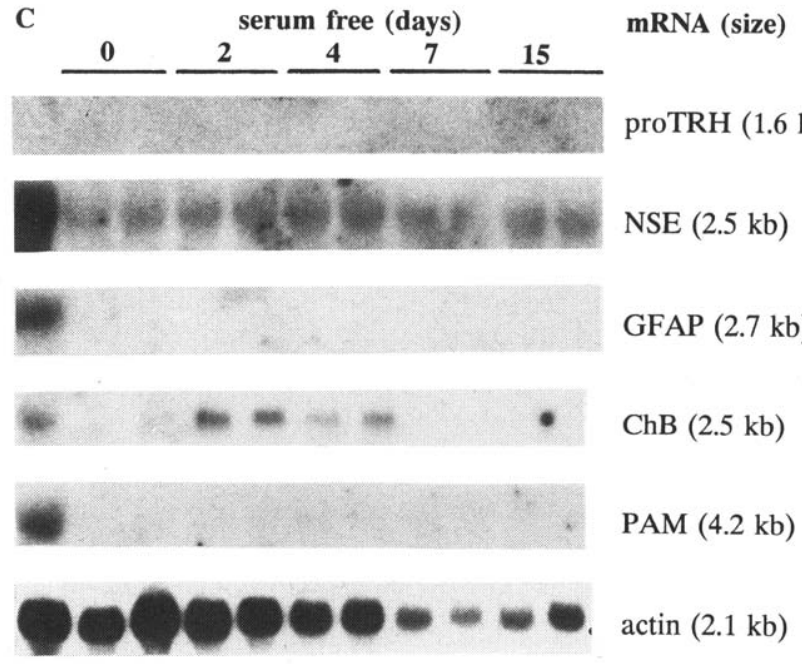

Fig. 3. Northern blot analysis of proTRH, neuron-specific enolase (NSE), glial fibrillary acidic protein (GFAP), chromogranin B (ChB), peptidylglycine $\alpha$-amidating enzyme (PAM) and actin mRNA during differentiation of IMR32 cells. Cells were grown in serum-containing medium until near confluency (d0) and subsequently in serum-free medium for 15 days. Total RNA was extracted on day $0,2,4,7$ and 15. Lanes consist of separate samples of $20 \mu \mathrm{g}$ RNA. Rat cortex was used as a control (C). The signal of PAM mRNA is only faintly visible. Same results were obtained in two other experiments.

Fig. 3 shows that neuroblastoma cells expressed the neuron-specific marker NSE, irrespective of differentiation. As described previously [9], in rat cortex a $2.5 \mathrm{~kb}$ band was detected. The glial-specific markers GFAP, NF68 and PLP were not expressed in these neuroblastoma cells, whereas their expression in rat cortex showed the mRNA signals of $2.7 \mathrm{~kb}$ for GFAP, 2.5 and $4 \mathrm{~kb}$ for NF68 (not shown), and 3.2 and $1.6 \mathrm{~kb}$ for PLP (not shown). ProTRH mRNA could not be detected in these cells by Northern blot analysis. Rat cortex did not contain proTRH mRNA, whereas rat hypothalamus contained abundant message (not shown). These cells also express the mRNA of PAM ( $4.2 \mathrm{~kb}$, faintly visible irrespective of differentiation) and of chromogranin B. The expression of the latter is dependent on differentiation since undifferentiated cells do not express this marker. After 7 and 15 days serum-free conditions no chromogranin $B$ signal could be detected, but this probably was caused by low recovery since also the actin mRNA signal declined in these periods.

To study what TRH-like peptide accounted for the immunoreactivity measured with the TRH-nonspecific antiserum 4319 , we applied pooled medium from undifferentiated and differentiated cells to a QAE Sephadex A-25 anion-exchange column after purification on Sep-Pak C18. Fig. 4 shows that TRH-IR in medium from differentiated cells was totally accounted for by a negatively charged molecule co-eluting with synthetic <EEP-NH $\mathrm{N}_{2}$, approximately 5 fractions before $\left[{ }^{125} \mathrm{I}\right] \mathrm{TRH}-\mathrm{Gly}$ which was used as a marker. Frac-

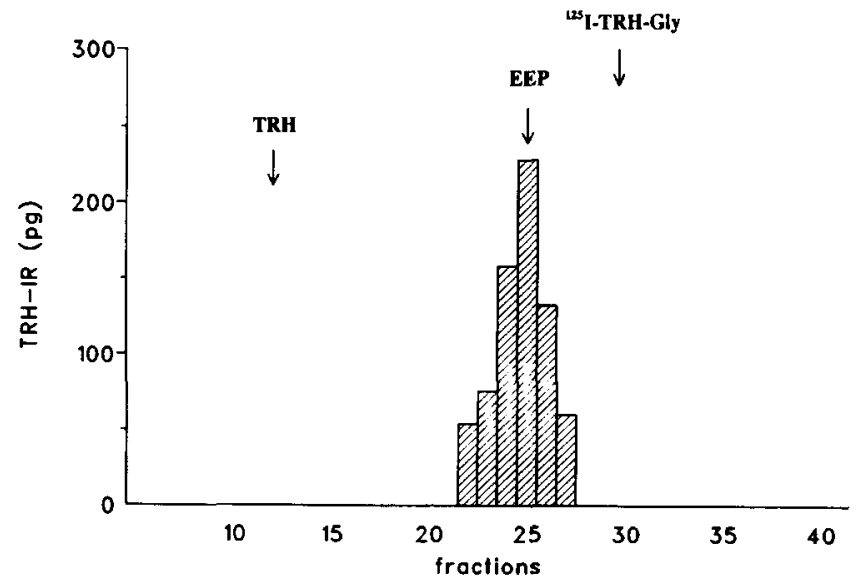

Fig. 4. Analysis of pooled medium from differentiated cells by anion-exchange chromatography. Cells were grown in serum-containing medium until near confluency and subsequently in serum-free medium for 12 days. Pooled medium was purified on Sep-Pak C18 columns and the subsequently pooled and air-dried methanol fractions were applied to a QAE Sephadex A-25 column. [ ${ }^{125}$ I]TRH-Gly was used as a marker. Elution positions of standards added to cell culture medium treated in the same way as experimental medium are depicted by arrows. Fractions were directly assayed by RIA with antiserum 4319. It is shown that TRH-IR in medium of differentiated cellls coelutes with synthetic pGlu-Glu-Pro- $\mathrm{NH}_{2}\left(<\right.$ EEP- $\mathrm{NH}_{2}$ $=$ EEP). The TRH-specific antiserum 8880 could not detect TRH-IR in these fractions.

tions containing TRH-IR were pooled, purified on Sep-Pak C18 and analyzed on HPLC. Fig. 5 shows that TRH-IR again co-eluted with synthetic < EEP-NH ${ }_{2}$. Media from undifferentiated cells did not contain TRH-IR (data not shown).

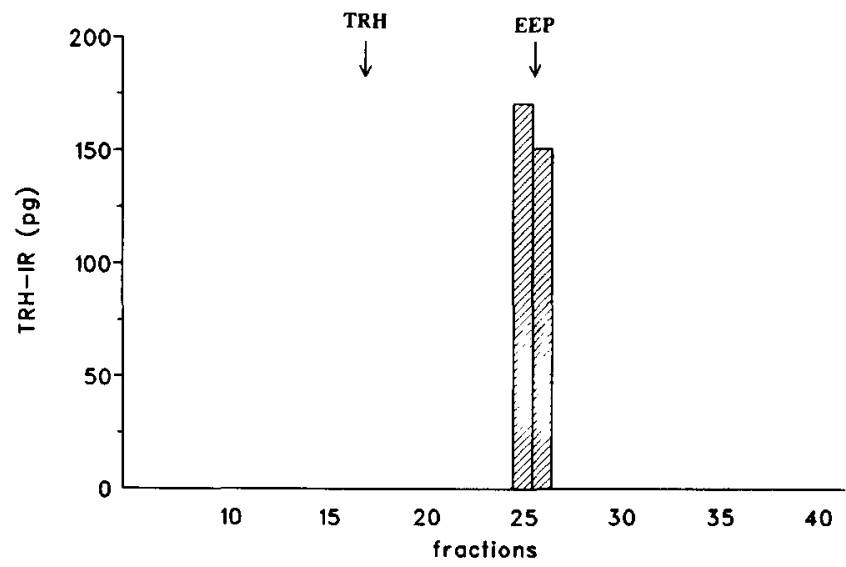

Fig. 5. Analysis of pooled fractions containing TRH-IR after anionexchange chromatography as described in Fig. 4. Pooled fractions were desalted on Sep-Pak C18 columns and the subsequently pooled and air-dried methanol fractions were applied to a Vydac C18 reverse phase HPLC column. Elution positions of standards are depicted by arrows. Fractions were directly assayed by RIA with antiserum 4319. It is shown that TRH-IR in the pooled fractions coelutes with synthetic pGlu-Glu-Pro-NH $\mathrm{NH}_{2}\left(<\mathrm{EEP}-\mathrm{NH}_{2}=\mathrm{EEP}\right)$. The TRH-specific antiserum 8880 could not detect TRH-IR in these fractions. 


\section{Discussion}

Neuroendocrine research of molecular mechanisms regulating synthesis of hypothalamic hormones is seriously hampered because of the lack of naturally occurring neural cell lines producing such hormones [32]. Neuroblastoma cells have the capacity to express multiple phenotypes, including neuronal, neurilemmal, and melanocytic characteristics despite the fact that they are derived from common neuroblast progenitor cells. This phenomenon of coordinate biochemical and morphologic interconversion is called transdifferentiation and suggests that these cells are pluripotent and capable of expressing multiple neural crest-derived phenotypes [1]. A particular path of differentiation is dependent on the differentiating agent used but also on the specific commitment of the cell to a Schwann cell, neuron cell or melanocytic pathway. The presence of NSE mRNA and the absence of GFAP, NF and PLP mRNAs in IMR32 cells irrespective of differentiation suggests that these cells are committed to a neural cell pathway. Neuronally-differentiated neuroblastoma cells have been shown to contain neurotransmitter receptors $[12,24]$ and enzymes $[12,13,41]$. They produce a number of neurotransmitters such as dopamine, noradrenaline and serotonin [13], and contain noradrenergic uptake systems [30]. Furthermore, these cells contain neuropeptide receptors $[14,29]$, the enzymatic machinery for prohormone processing [25] and neurosecretory organelles [13,34]. They synthesize neuropeptides such as enkephalins [27], VIP [5,15,37], PHM [15] and neuropeptide $\mathrm{Y}[26,36]$, and contain neuropeptide-degrading enzymes [45]. Since the ubiquitous TRH is also located in neural crest derivatives like the spinal cord [2] and the adrenal gland [38], we hypothesized that differentiated neuroblastoma cells might produce TRH and thus constitute a model of neural proTRH gene expression. These cells, however, do not express the proTRH gene since we could not detect TRH-IR with our TRH-specific antiserum 8880 , and Northern blot analysis failed to reveal the presence of proTRH mRNA in these cells. Also in situ hybridization analysis could not detect proTRH mRNA in IMR32, irrespective of differentiation (J.M.M. Rondeel, personal observation). Analysis by anion-exchange chromatography revealed that these cells produce a negatively charged TRH-like peptide coeluting with synthetic pGlu-Glu-ProNH $\mathrm{N}_{2}\left(<\right.$ EEP-NH$\left.{ }_{2}\right)$. This finding was confirmed by a second chromatographic analysis using reverse phase HPLC. Although only amino acid analysis can reveal the exact nature of the TRH-like peptide, from our chromatographic and RIA data we can draw several conclusions. Firstly, because of the nature of antigen recognition of our TRH antisera, the TRHlike peptide has to be C-terminally amidated and $\mathrm{N}$ terminally cyclized. Secondly, retention of the TRH-like peptide during anion-exchange chromatography confirms its negative charge. Since the middle amino acid residue determines the overall charge of this tripeptide, its structure has to be pGlu-Glu-ProNH $\mathrm{N}_{2}$ or pGlu-Asp-ProNH $\mathrm{N}_{2}$, which has not been characterized before. Coelution with synthetic pGlu-Glu-ProNH $\mathrm{N}_{2}$ in two different chromatographic systems strongly suggests that this tripeptide accounts for TRH-IR produced by these cells. In addition, synthetic pGlu-Asp$\mathrm{ProNH}_{2}$ (courtesy of Dr. W.J.A. Boersma, TNO, Rijswijk, The Netherlands) does not crossreact in RIA with antiserum 4319, whereas its retention time on HPLC differs from that of pGlu-Glu-ProNH ${ }_{2}$ (unpublished).

Production of pGlu-Glu-ProNH $\mathrm{H}_{2}$ is dependent on differentiation grade. Differentiation characteristics include morphological, biochemical and electrophysiological parameters. Neurally differentiated cells show a typically neural-like appearance $[12,34,41]$, express neuron-specific markers, while glial-specific markers are absent (present study) and behave as neurons in electrophysiologic studies [1,12]. The production of neuropeptides and the expression of chromogranin $\mathrm{B}$ mRNA [10] can be viewed as another characteristic of neuroendocrine differentiation. Interestingly, there is a good correlation between morphological differentiation and production of the TRH-like peptide by these cells. Peptide production is first detectable during initial differentiation (day 3-5) and shows a plateau when differentiation characteristics are maximal (day 12). In only one other study was neutral or acidic TRH-IR localized in the nervous system, principally in the hippocampus, brain stem and dorsal colliculi but the exact nature of the TRH-IR was not further characterized [31]. A recent report showed the presence of TRH-IR in human benign prostate hyperplasia, while in prostate cancer no TRH-IR could be detected [11]. Again, these latter findings imply that the presence or absence of TRH-IR is dependent on differentiation grade.

Since TRH-like peptides are C-terminally amidated it is obvious that their production is also dependent on the presence of an $\alpha$-amidating enzyme. Indeed, these cells express the mRNA of PAM and its expression is irrespective of differentiation.

The TRH-like peptide pGlu-Glu-ProNH $\mathrm{H}_{2}$ is present in the pituitary [3] and the genital tract [4]. A recent study suggests that it might influence motility of spermatozoa [40]. As yet its precise function and biological significance, however, are unknown, although the presence of a C-terminally amidated $\mathrm{ProNH}_{2}$ points to biological activity [8]. Its TRH-like appearance causes it to crossreact with a number of antisera that are being used in RIA, since most of these antisera react specifically with the $\mathrm{N}$-terminal pGlu and the C-terminal ProNH2 and are less specific for the His residue. Therefore, most of the TRH-IR found in the prostate 
can be attributed to pGlu-Glu-ProNH ${ }_{2}$ [4]. It should be mentioned, however, that this is the only reason to call this peptide TRH-like: the proTRH gene lacks codons that could give rise to pGlu-Glu-ProNH ${ }_{2}$ [17] and this novel tripeptide is unlikely to interact with the TRH receptor because of its negative charge at physiologic pH [28].

Our two antisera, of which one is TRH-specific and the other nonspecific and reacting with any tripeptide pGlu-X-ProNH2, should forward the study of the localization and biological significance of TRH-like peptides. Furthermore, molecular mechanisms regulating pGlu-Glu-ProNH $\mathrm{N}_{2}$ synthesis can now be studied in neuroblastoma cells dependent on a well-defined biological process like neural differentiation. Mechanisms regulating neural differentiation and thus production of neuropeptides may be extrapolated to other cells, e.g. hypothalamic neurons, to establish cell culture systems producing hypothalamic hormones. Indeed, we recently reported that the differentiating agent bromo-deoxy-uridine that is known to induce differentiation in neuroblastoma cells [12], markedly enhances production of TRH in fetal hypothalamic neurones in primary culture [6].

\section{Acknowledgments}

J.M.M. Rondeel is the recipient of a fellowship of the Royal Netherlands Academy of Arts and Sciences. This work was supported in part by a grant from the Diabetes Fonds Nederland.

\section{References}

[1] Abemayor, E. and Sidell, N., Human neuroblastoma cell lines as models for the in vitro study of neoplastic and neuronal cell differentiation, Environ. Health Perspect., 80 (1989) 3-15.

[2] Appel, N.M., Wessendorf, M.W. and Elde, R.P., Thyrotropinreleasing hormone in spinal cord: coexistence with serotonin and with substance $P$ in fibers and terminals apposing identified preganglionic sympathetic neurons, Brain Res., 415 (1987) 137143.

[3] Ashworth, R.J., Morrell, J.M., Aitken, A., Patel, Y. and Cockle, S.M., Pyroglutamylglutamylprolineamide is present in rat anterior and posterior pituitary gland, J. Endocrinol, 129 (1991) R1-R4.

[4] Bilek, R., Gkonos, P.J., Tavianini, M.A., Smyth, D.G. and Roos, B.A., The thyrotrophin-releasing hormone (TRH)-like peptides in rat prostate are not formed by expression of the TRH gene but are suppressed by thyroid hormone, J. Endocrinol., 132 (1992) 177-184.

[5] Brick, P.L., Howlett, A.C. and Beinfeld, M.C., Synthesis and release of vasoactive intestinal polypeptide (VIP) by mouse neuroblastoma cells: modulation by cyclic nucleotides and ascorbic acid, Peptides, 6 (1985) 1075-1078.

[6] Bruhn, T.O., Rondeel, J.M.M., Bolduc, T.G. and Jackson, I.M.D., Induction of TRH and SRIF gene expression in cul- tured hypothalamic neurons by differentiating agents, 75th $\mathrm{An}$ nual Meeting of The Endocrine Society, Las Vegas, NV, 1993 (Abstract).

[7] Chomczynski, P. and Sacchi, N., Single-step method of RNA isolation by acid guanidinium thiocyanate-phenol-chloroform extraction, Analyt. Biochem., 162 (1987) 156-159.

[8] Eipper, B.A., Stoffers, D.A. and Mains, R.E., The biosynthesis of neuropeptides: peptide $\alpha$-amidation, Annu. Rev. Neurosci., 15 (1992) 57-85.

[9] Forss-Petter, S., Danielson, P. and Sutcliffe, J.G., Neuronspecific enolase: complete structure of rat mRNA, multiple transcriptional start sites, and evidence suggesting post-transcriptional control, J. Neurosci. Res., 16 (1986) 141-156.

[10] Forss-Petter, S., Danielson, P., Battenberg, E., Bloom, F. and Sutcliffe, J.G., Nucleotide sequence and cellular distribution of rat chromogranin B (secretogranin I) mRNA in the neuroendocrine system, J. Mol. Neurosci., 1 (1989) 63-75.

[11] Gkonos, P.J., Kwok, C.K., Block, N.L. and Roos, B.A., Expression of prostatic TRH-like peptides differs between species and between malignant and nonmalignant tissues, The Prostate, 23 (1993) 135-147.

[12] Gotti, C., Sher, E., Cabrini, D., Bondiolotti, G., Wanke, E., Mancinelli, E. and Clementi, F., Cholinergic receptors, ion channels, neurotransmitter synthesis, and neurite outgrowth are independently regulated during the in vitro differentiation of a human neuroblastoma cell line, Differentiation, 34 (1987) 144155.

[13] Gupta, M., Notter, M.F.D., Felten, S. and Gash, D.M., Differentiation characteristics of human neuroblastoma cells in the presence of growth modulators and antimitotic drugs, Dev. Brain. Res., 19 (1985) 21-29.

[14] Hochhaus, G., Yu, V.C. and Sadee, W., Delta opioid receptors in human neuroblastoma cell lines, Brain Res., 382 (1986) 327331.

[15] Hoshino, M., Yanaihara, C., Ogino, K., Iguchi, K., Sato, H., Suzuki, T. and Yanaihara, N., Production of VIP- and PHM (human PHI-)-related peptides in human neuroblastoma cells, Peptides, 5 (1984) 155-160.

[16] Kakucska, I. and Lechan, R.M., Adrenal status affects TRH but not somatostatin gene expression in the hypothalamus, 73rd Annual Meeting of The Endocrine Society, Washington DC, 1991 (Abstract).

[17] Lechan, R.M., Wu, P. and Jackson, I.M.D., Thyrotropin-releasing hormone precursor: characterization in rat brain, Science, 231 (1986) 159-161.

[18] Lee, S.L. and Sevarino, K.A., Molecular assays for rat thyrotropin-releasing hormone gene, Methods Neurosci., 5 (1991) 34-44.

[19] Lewis, S., Balcarek, J.M., Krek, V., Shelanski, M. and Cowan, N.J., Sequence of a cDNA encoding mouse glial fibrillary acidic protein: structural conservation of intermediate filaments, Proc. Natl. Acad. Sci. USA, 81 (1984) 2743-2746.

[20] Lewis, S.A. and Cowan, N.J., Genetics, evolution, and expression of the $68,000-\mathrm{mol}-\mathrm{wt}$ neurofilament protein: isolation of a cloned cDNA probe, J. Cell. Biol., 100 (1985) 843-850.

[21] Mellon, P.L., Windle, J.J., Goldsmith, P.C., Padula, C.A. Roberts, J.L. and Weiner, R.I., Immortalization of hypothalamic GnRH neurons by genetically targeted tumorigenesis, Neuron, 5 (1990) $1-10$.

[22] Milner, R.J., Lai, C., Nave, K-A., Lenoir, D., Ogata, J. and Sutcliffe, J.G., Nucleotide sequences of two mRNAs for rat brain myelin proteolipid protein, Cell, 42 (1985) 931-939.

[23] Mugele, K., Kugler, $\mathbf{H}$. and Spiess, J., Immortalization of a fetal rat brain cell line that expresses corticotropin-releasing factor mRNA, DNA Cell. Biol., 12 (1993) 119-126.

[24] Neijt, H.C., Vijverberg, H.P.M. and Bercken van den, J., The dopamine response in mouse neuroblastoma cells is mediated 
by serotonin 5HT3 receptors, Eur. J. Pharmac,, 127 (1986) 271-274.

[25] Noel, G., Zollinger, L., Laliberte, F., Rassart, E., Crine, P. and Boileau, G., Targeting and processing of pro-opiomelanocortin in neuronal cell lines, J. Neurochem., 52 (1989) 1050-1057.

[26] O'Hare, M.M.T. and Schwartz, T.W., Expression and precursor processing of neuropeptide $\mathrm{Y}$ in human and murine neuroblastoma and pheochromocytoma cell lines, Cancer Res., 49 (1989) 7015-7019.

[27] Palmisano, A., D'Auria, S., Sannia, G., Marino, G. and Tocco, G., Preproenkephalin mRNA in neuroblastoma $\times$ glioma, NG $108-15$, hybrid cells and in parental cell lines: mouse neuroblastoma, N18, and rat glioma, C6, Neuropeptides, 10 (1987) 321-327.

[28] Perlman, J.F., Nussenzveig, D.R., Osman, R. and Gershengorn, M.C., Thyrotropin-releasing hormone binding to the mouse pituitary receptor does not involve ionic interactions. A model for neutral peptide binding to $G$ protein-coupled receptors, $J$. Biol. Chem., 267 (1992) 24413-24417.

[29] Poustis, C., Mazella, J., Kitabgi, P. and Vincent, J.P., High-affinity neurotensin binding sites in differentiated neuroblastoma N1E115 cells, J. Neurochem., 42 (1984) 1094-1100.

[30] Richards, M.L. and Sadee, W., Human neuroblastoma cell lines as models of catechol uptake, Brain Res., 384 (1986) 132-137.

[31] del Rio-Garcia, J. and Smyth, D.G., Distribution of pyroglutamylpeptide amides related to thyrotrophin-releasing hormone in the central nervous system and periphery of the rat, $J$. Endocrinol., 127 (1990) 445-450.

[32] Rondeel, J.M.M. and Jackson, I.M.D., Molecular biology of the regulation of hypothalamic hormones, J. Endocrinol. Invest., 16 (1993) 219-246.

[33] Sevarino, K.A., Wu, P., Jackson, I.M.D. and Roos, B.A., Mandel, G. and Goodman, R.H., Biosynthesis of thyrotropin-releasing hormone by a rat medullary thyroid carcinoma cell line, $J$. Biol. Chem., 263 (1988) 620-623.

[34] Sher, E., Denis-Donini, S., Zanini, A., Bisiani, C. and Clementi, $F$, Human neuroblastoma cells acquire regulated secretory properties and different sensitivity to $\mathrm{Ca}^{2}+$ and $\alpha$-latroxin after exposure to differentiating agents, J. Cell. Biol, 108 (1989) 2291-2300.

[35] Stoffers, D.A., Green, C.B. and Eipper, B.A., Alternative mRNA splicing generates multiple forms of peptidyl-glycine alphaamidating monooxygenase in rat atrium, Proc. Natl. Acad. Sci. USA, 86 (1989) 735-739.

[36] Suburu, A.M., Wheatley, S.C., Horn, D.A., Gibson, S.J., Jahn, R., Fischer-Colbrie, R., Wood, J.N., Latchman, D.S. and Polak, J.M., Intracellular redistribution of neuropeptides and secretory proteins during differentiation of neuronal cell lines, Neuroscience, 46 (1992) 881-889.

[37] Svoboda, M., Gregoire, A., Yanaihara, N. and Christophe, J., Identification of two pro-VIP forms in a human neuroblastoma cell line, Peptides, 7 (1986) 7-15.

[38] Tal, E., Mohari, K., Kovacs, Z., Kocsar, L. and Endroczi, E., Thyrotropin releasing hormone (TRH) distribution in the rat adrenal gland, Horm. Metab. Res., 16 (1984) 453.

[39] Tavianini, M.A., Gkonos, P.J., Lampe, T.H. and Roos, B.A., Dexamethasone stimulates thyrotropin-releasing hormone production in a C cell line, Mol. Endocrinol., 3 (1989) 605-610.

[40] Thetford-Mayes, C.R., Morrell, J.M. and Cockle, S.M., TRH-related peptides in the rabbit prostate complex during development, Biochim. Biophys. Acta, 1115 (1992) 252-258.

[41] Tsokos, M., Scarpa, S., Ross, R.A. and Triche, T.J., Differentiation of human neuroblastoma recapitulates neural crest development, Am. J. Pathol., 128 (1987) 484-496.

[42] Tumilowicz, J.J., Nichols, W.W., Cholon, J.J. and Greene, A.E., Definition of a continuous human cell line derived from neuroblastoma, Cancer Res., 30 (1970) 2110-2118.

[43] Visser, T.J., Klootwijk, W., Docter, R. and Henneman, G., A new radioimmunoassay of thyrotropin-releasing hormone, FEBS Lett., 83 (1977) 37-40.

[44] Yamada, M., Radovick, S., Wondisgord, F.E., Nakayama, Y. Weintraub, B.D. and Wilber, J.F., Cloning and structure of human DNA and hypothalamic cDNA encoding human preprothyrotropin-releasing hormone, Mol. Endocrinol., 4 (1990) 551556.

[45] Yokosawa, H., Fujii, Y. and Ishii, S., Degradation of luteinizing hormone-releasing hormone by neuroblastoma cells and their membrane: evidence for the involvement of a thiol protease and angiotensin-converting enzyme, $J$. Neurochem., 48 (1987) 293298. 